www.volsu.ru

DOI: https://doi.org/10.15688/nav.jvolsu.2021.1.10

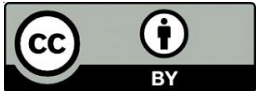

UDC 7.045

Submitted: 05.03.2020

LBC 63.400

Accepted: 27.05 .2021

\title{
TWO SARMATIAN STONE SLABS WITH TAMGAS IN ODESSA ARCHEOLOGICAL MUSEUM COLLECTIONS
}

\author{
Sergey A. Yatsenko \\ Russian State University for the Humanities, Moscow, Russian Federation
}

\begin{abstract}
Based on a series of high-quality photos, new analysis was performed for tamgas along with animal and male images on Sarmatian stone slabs from Kryvyi Rih and from Gorgippia. Both stone slabs were created as a result of natural shape stones edges chipping; both were dug into the ground and functioned as the mini-shrines located, probably, in sacred places or at the settlement entrances. They are similar in size, both painted red and both contain a number of sacrificial recesses at the top (in the sacred numbers 3 or 7). Slab from Kryvyi Rih (Figs. 1-2) depicts large earliest signs (mostly used on territories of Western Ukraine and the "barbarian" parts of Crimea) placed around the head of a god with animal ears (similar to the Ossetian Afsati). The later minor signs include the largest number of the Lower Don and the Central Asia (Kangju, Khorezm) tamgas. Also the signs of the kings found here (the ruler of Khorezm - no. 9, the co-ruler of Tiburius Julius Eupator of Bosporus - no. 8). The complex of images was in use since the beginning of the $1^{\text {st }}$ until the middle of the $3^{\text {rd }}$ centuries CE. Five hands of different men are depicted in relief on the stone slab from Gorgyppia (Fig. 3). There are three hands with goblets for making a contract and a quiver with a belt in front of them (probable heroization motif). There are also a hand raised for prayer and a hand passing a quiver. Those three participants match three tamgas (belonging to the "barbarian" regions of Crimea) and three sacrificial recesses at the top. All the images on the slab were probably made at the same time, shortly after the middle of the $2^{\text {nd }} \mathrm{c}$. CE.

Key words: Sarmatian stone slabs with tamgas, mini-shrines, the $1^{\text {st }}-3^{\text {rd }} \mathrm{cc}$. CE, worship of the God Master of Animals, ritual of making a contract, principles of tamgas placement near zoomorphic and anthropomorphic images.

Citation. Yatsenko S.A., 2021. Dve sarmatskih kamennyh plity s tamgami iz kollektsii Odesskogo arheologicheskogo muzeya [Two Sarmatian Stone Slabs with Tamgas in Odessa Archeological Museum Collections]. Nizhnevolzhskiy Arkheologicheskiy Vestnik [The Lower Volga Archaeological Bulletin], vol. 20, no. 1, pp. 204-216. DOI: https://doi.org/10.15688/nav.jvolsu.2021.1.10
\end{abstract}

УДК 7.045

ББК 63.400

Дата поступления статьи: 05.03.2020

Дата принятия статьи: 27.05.2021

\section{ДВЕ САРМАТСКИХ КАМЕННЫХ ПЛИТЫ С ТАМГАМИ ИЗ КОЛЛЕКЦИИ ОДЕССКОГО АРХЕОЛОГИЧЕСКОГО МУЗЕЯ}

\section{Сергей Александрович Яценко}

Российский государственный гуманитарный университет, г. Москва, Российская Федерация

\begin{abstract}
Аннотация. На основе серии качественных фото дан более корректный анализ тамг, а также зооморфных и мужских изображений на сарматских каменных плитах из Кривого Рога и из Горгиппии. Обе плиты были созданы в результате обкалывания краев у камней природной формы, вкопаны в грунт и являлись мини-святилищами, расположенными, вероятно, в святом месте или у въезда в поселения. Они близки по размерам, окрашены в красный цвет и содержали вверху ряд углублений для жертвоприношений (их количество - священные числа 3 или 7). В Кривом Роге (рис. 1-2) вокруг головы бога с ушами животного (аналогичного осетинскому Афсати) размещены крупные первоначальные знаки, более всего - бытовавших на Западной Украине и в «варварских» частях Крыма, более поздние мелкие знаки включают наибольшее число тамг Нижнего Дона и Центральной Азии (Кангюй, Хорезм). Здесь встречены также знаки царей (правитель Хорезма - № 9, соправитель Тиберия Юлия Эвпатора Боспорского - № 8). Комплекс изображений функционировал с начала I по середину III вв. н.э. На плите из Горгиппии (рис. 3) рельефно изображены пять рук разных (2) мужчин: три руки с бокалами для заключения договора, перед ними - колчан с поясом (мотив героизации?),
\end{abstract}


а также рука, поднятая для молитвы, и рука, подающая колчан. Трем участникам соответствуют три тамги (они принадлежат «варварским» районам Крыма) и три углубления наверху для жертвоприношений. Все изображения на ней, вероятно, сделаны одновременно, вскоре после середины II в. н.э.

Ключевые слова: сарматские каменные плиты с тамгами, мини-святилища, I-III вв. н.э., поклонение богу Хозяину животных, ритуал заключения договора, принципы размещения тамг у зооморфных и антропоморфных изображений.

Цитирование. Яценко С. А., 2021. Две сарматских каменных плиты с тамгами из коллекции Одесского археологического музея // Нижневолжский археологический вестник. Т. 20, № 1. С. 204-216. DOI: https:// doi.org/10.15688/nav.jvolsu.2021.1.10

В статье речь пойдет о двух широко известных плитах с сарматскими тамгами, которые неоднократно публиковались [Юргевич, 1889, с. 504-505; Козыренко, 1957, табл. 1,4; Соломоник, 1959, №№ 31, 43; Яценко, 1992а, рис. 4,1-2; 2001, с. 68-69, 82, рис. 12], но, увы, с низким качеством фото или немалыми неточностями в прорисовках. Обе плиты, на мой взгляд, важны для понимания ряда аспектов сарматских культур римского времени. Первая из плит происходит из района г. Кривой Рог (Правобережная Украина, бассейн р. Ингулец у нынешней северной границы степной зоны). Она была куплена в 1887 г. Императорским Одесским обществом истории и древностей и вскоре кратко описана одним из руководителей общества, литовским поляком по происхождению, Владиславом Норбертовичем Юргевичем. Другая поступила в музей Общества из Анапы (древней Горгиппии на Азиатском Боспоре). В документации Общества фиксировался район находки каждой плиты (приобретались они на месте), но, его членов, к сожалению, не интересовали специально точное место и обстоятельства находки.

Обе плиты уже давно вмонтированы вертикально в бетонные постаменты для экспонирования в одном из залов Одесского археологического музея. До этого момента Э.И. Соломоник имела возможность наблюдать их нижние выступы-шипы (плиты из Горгиппии это касается лишь частично, так как в 1950-е годы она была вмонтирована иначе, чем сегодня). Плиты имеют следы (к счастью - очень небольшие) их транспортировки на большое расстояние в Одессу (преимущественно горизонтальные легкие царапины, полоски коричневой краски, несколько меток, недавно сделанных тонким стальным лезвием). Несмотря на свободный доступ к ним в экспозиции музея и их сравнительно небольшие размеры, сфотографировать их в нужном освещении и масштабе и во всех необходимых ракурсах (чтобы были хорошо видны частично стертые, поврежденные или прочерченные тонкими лезвиями знаки и линии) долгое время было невозможным. Несколько лет назад большую серию таких цветных и черно-белых фото подготовила сотрудница музея Елена Борисовна Шевченко, любезно предоставившая их мне. Эта, вынужденно ограниченная по объему и числу иллюстраций статья является лишь предварительной публикацией. Однако ряд важных особенностей обоих памятников и часть наблюдений по ним можно представить уже сейчас.

Первой (и довольно сложной) моей задачей было составление на основе множества разноплановых качественных фото корректных прорисовок обеих каменных плит в их основных ракурсах. Это прорисовки являются здесь основным источником. К сожалению, в определении размеров этих двух невеликих плит имеются немалые расхождения в монографии Э.И. Соломоник, в музейных карточках на экспонаты и в сравнительно недавно сделанных Е.И. Шевченко замерах (которым я доверяю в первую очередь). Отдельная проблема - установление формы и размеров нижних «шипов» этих плит: они давно вмурованы в бетонные постаменты. По наиболее раннему замеру Э.И. Соломоник, высота плиты из Горгиппии -130 см, по недавнему замеру - 110 см, по описанию к карточке экспоната - 107 см.

Со временем бросаются в глаза некоторые важные элементы сходства в оформлении этих, на первых взгляд, совершенно несхожих объектов явно «варварской» работы (между пунктами находок которых - около 800 км тогдашнего дорожного расстояния по 
самому короткому маршруту - через Керченский пролив). 1. Обе плиты имеют сходные размеры: высота (вместе с «шипом» для закрепления вертикально в грунте) по Э.И. Соломоник -120 см (Кривой Рог) и 130 см (Горгиппия); согласно последним замерам, ширина их (максимальная и максимальная), соответственно - 81-47 и 81-47 см (то есть по ширине они практически идентичны); толщина, соответственно - 20-16 и 25-15 см; верхняя площадка, соответственно - 20-66 и 20-48 см. Коллег-античников мой вопрос о соответствии этих параметров поздней греко-римской метрологии или локальным боспорским традициям, похоже, застал врасплох. Но, по любезному сообщению С.В. Кашаева (ИИМК РАН) от 03.03.2021, часть плит римского времени из Вышестеблиевской-11 на Тамани по ширине близка 47 см... 2. Обе плиты в древности были окрашены красной краской, как минимум - на отдельных участках (на плите из Кривого Рога ее остатки сохранились визуально на многих участках на торцах и верхней площадки, на плите из Горгиппии - в верхней части. 3. Обе плиты вblполняли, помимо, прочего, функиии так называемых «чамечных камней»: по верхней кромке плиты, обращенной к лицевой стороне, шел ряд небольших углублений (отчасти подправленных естественных, отчасти выдолбленных) для жертвенных крови, молока или жира: семь ямок на артефакте из Кривого Рога (рис. $2, a-g$ ) и три - на горгиппийском (рис. 3, $a-c$ ). В последнем случае в углублениях сохранилась красная краска. В обоих случаях количество ямок составляет священное число (3 или 7). Использовали ли сарматы римского времени «чашечные камни»? Да, конечно. Например, в Буджаке в некрополе рубежа II-III вв. н.э. Хаджидер II группа погребений размещалась полукольцом вокруг своеобразного мини-святилища - «кургана 10»пустой ямы, вдоль одной из стенок которой был вертикально установлен «чашечный камень» [Яценко, 2018а, с. 226, рис. 5,1]. 4. Обе плиты имели сходный принции установки: их поверхность, хотя и весьма грубо, была выровнена со всех сторон (прежде всего лицевая и тыльная плоскости), что предусматривало регулярный обзор объекта с разных сторон; в грунте они закреплялись с помощью шипа на глубину около 20 см. 5. Одинаков $u$ принции размещения гравировок: они отсутствуют на тыльной стороне и на правом (по отношению к зрителю) торце, концентрируются на лицевой стороне; в небольшом числе они есть на верхней площадке (наряду с «чашечными» углублениями) и по одной - на левом торце. 6. Скопление изображений на лицевой стороне имеет выраженный композииионный иентр с включением живых существ. С ним связано и размещение сопровождающих знаков-тамг (на изделии из Кривого Рога последние располагались вокруг, что особенно заметно по первоначальным крупным знакам, причем для кругового размещения для многих знаков пришлось поменять их наиболее принятую ориентацию в пространстве; на артефакте из Горгиппии они располагались косой линией влево и вниз от центра, уменьшаясь в размерах).

Думается, обе плиты, в силу важности представленных на них сюжетов, располагались не на кургане (принадлежавшем конкретному лицу или его семье), не на площади грунтового городского некрополя (как могло бы быть в Горгиппии) и не в населенном пункте, а в неких святых местах (у священных источников или рощи, природных гротов, на перекрестке дорог, у въезда в город (Горгиппия), на границе племенных территорий (Кривой Рог) и т. п. Почти одновременное размещение на них знаков сарматских кланов с совершенно разных территорий (для чего их представители нередко приезжали издалека) заставляет усомниться в частном или фамильном характере подобных плит со скоплениями разномастных тамг. Убеждает в этом и обзор сюжетных изображений, дающийся ниже.

Методика изучения специфической и многоплановой знаковой системы, какой являются метки идентичности типа «nishan / tamga» (у них насчитывают не менее восьми функций) на сегодня уже достаточно основательно проработана в рамках ряда международных проектов [Perrin et al., 2010; Яценко и др., 2019, с. 8-42]. За последние годы на разных территориях Евразии накоплен и обобщен обширный материал по таких знакам. Все это существенно облегчает мою задачу по анализу тамг на одесских плитах. 
Рассмотрим теперь каждую из этих интереснейших известняковых плит поподробнее.

1. Плита из Кривого Рога (Кривий Ріг), инв. № 50750 (рис. 1-2). Основная поверхность плиты имеет форму неправильного овала. В вертикальном сечении это достаточно правильной формы вытянутый прямоугольник. Передняя и задняя плоскости, как и борта, обработаны не пилением, а обкалыванием ненужных деталей. Небольшие сколы есть по левой передней кромке плиты. В центре изображена голова существа, напоминающего лошадь, причем предварительная неудачная проба изображения нижней части личины располагается рядом [Соломоник, 1959, с. 97]. Из ее деталей выделены длинные заостренные уши, круглые глаза и два выступающих нижних зуба-резца, а также странные завитки, идущие от основания челюстей. Действительно, скопления сарматских тамг сопровождаются из животных обычно именно лошадьми [Яценко, 2001, с. 63-64]. Однако вряд ли простая лошадиная голова стала бы центром большой композиции - мини-святилища с не менее чем 48 тамгами. Более вероятной представляется другая версия: речь идет о голове божества с ушами животного, образ которого (Хозяин Животных, вроде позднего осетинского Афсати) известен многим иранским, шире - индовропейским и иным народам Евразии [Яценко, 1992а, с. $193-194 ; 19926$, с. 65 , рис. $1,1-3]$.

Несмотря на не совсем ровные поверхности плиты (лицевую и верхнюю плоскости), почти все тамги разного размера их хозяева постарались нанести на этом сакральном объекте аккуратно, близко к «nечатной» форме. Исключениями можно считать (лишь отчасти) знаки № 8 и № 17 слева и справа от головы (рис. 2). Это тоже говорит о значении комплекса. Как обычно в таких случаях, знаки никогда не перекрывают друг друга (при тогдашних обычаях это имело бы для инициатора печальные последствия). Не исключено, что к древности относится и один знак, нанесенный красной краской в углублении на левом торце (рис. 1). Интересно, что для нескольких знаков, больших и малых (обычно в верхней части лицевой стороны), перед нанесением каждого из них небольшой участок поверх- ности в форме полуовала был дополнительно выровнен (№№ 1, 4, 13, 19, 21, 35).

Как уже отмечалось, данное мини-святилище функционировало долго [Яценко, 2001, с. 68-69], и самые ранние знаки рубежан.э. - первой половины I в. н.э. (№ 4, № 17) здесь происходят из весьма удаленных от правобережной днепровской степи районов - Кубани (4/1) ${ }^{1}$ и Дона (4/9) (именно их хозяева были в числе первых, специально приходивших к плите для совершения обрядов (молений, клятв и т. п.).

Вокруг изображения головы представлены по кругу наиболее крупные знаки, сделанные, вероятно, в период основного функционирования это сакрального комплекса. Если мы учтем, из каких именно регионов представлены и как размещены эти знаки, мы яснее поймем и характер почитания этого объекта. Отмечу, что из пяти типов тамг (№№ $1,5,18$, 35,36 ), встреченных на плите дважды (что, вероятно, означало несколько визитов к плите), либо оба, либо один из них имеют крупный размер. Знаки среднесарматского времени господствуют в этом комплексе [Яценко, 2001, с. 68-69], в том числе - среди анализируемых сейчас крупных. Интересно и, думается, вполне закономерно их распределение по регионам степной Сарматии: прежде всего они представляют соседние районы Правобережной Украины, которые размещены по два по верхнему и по нижнему краям композиции (№№ 1 (дважды), 2, 28; см. 5/84, $5 / 90,5 / 100)$. Также три знака связаны с «варварскими» районами Крыма (все они расположены рядом, справа от головы: №№ 5, 34, $30 ;$ см. 5/14, 5/11; о знаке № 30 из могилы 40 в Битаке см. [Яценко, 2018б, рис. 3,№ 1; Яценко и др., 2019, с. 167-168]; он неоднократно встречается в Кангюйской державе на Средней Сырдарье, где в слое на Культобе Туркестанском пока датируется примерно рубежом II-III вв. н.э. [Яценко и др., 2020, рис. 6-2,90]). Две тамги связаны с Северным Приазовьем (№ 35 - дважды; см. 5/62) и одна - со Средней Кубанью (№ 18; см. 5/55, которая размещена вверху плиты и также - в центре композиции верхней плоскости). Тамг из более удаленных на восток районов (низовьев и верховьев Дона, Центрального и Восточного Предкавказья) среди крупных, главных знаков нет. 
Тамги №№ 7, 12, 15, 23, 36 пока нельзя привязать к конкретной территории (то же можно сказать и о двух крупных знаках на верхней плоскости, хотя левый, № 26, изображен на потолке крымской пещеры Ак-Кая-1). Самые поздние крупные знаки позднесарматского времени расположены справа от изображенной головы: он представляют, как и самые ранние, более восточные районы: «варварский〉 Крым (№ 3; см. 6/4) и Боспор (№ 8; см. 6/68). Боспорский образец является... тамгой соправителя царя Тиберия Юлия Евпатора (154 - ок. 173 гг. н.э.): последний, как предполагается, мог погибнуть в войне с сарматами.

Обратимся теперь $к$ мальмм знакам, которые явно наносились позже и вписывались в свободные участки. В этой серии знаки №№ 6, 10, 16, 19, 21, 23, 29 пока совершенно неопределимы, уникальны. Малые знаки всегда представлены только в одном экземпляpe. Половина из них (6 из 12) относятся к позднесарматскому времени середины II - середины III вв. н.э. Для определимых тамг распределение представленных по регионам в этой серии выглядит соврешенно иным. На первом месте количественно оказываются уже не местные, западноукраинские тамги, а далекие нижнедонские (4 экз., три из которых поздние); три из них расположены в тесный ряд ниже головы и один над нею: ранний, известный на золотых бляшках (№ 32; см. 5/41), и поздние (№ 24; см. 6/37; № 38; см. 6/30 и 6/33 - упряжь из кургана 1 в Кировском III) [Ильюков, 2000, рис. 19,3]).

Вторая по численности группа (3 экз.). происходит из куда более дальних государств тогдашней Средней Азии - Хорезма и Кангюя, с которыми некоторые сарматские группировки были связаны экономически, а с Кангюем также - генетически и (после середины I в. н.э.) политически [Яценко и др., 2019, с. 34-39, 61-66]. Обилие идентичных тамг в Сарматии и в Хорезме в римское время было весьма заметным на фоне соседних территорий [Яценко, 2001, с. 87-89]. Один из таких знаков можно считать едва ли не самым большим сюрпризом в изучении этого памятника. $B$ иентре упомянутой ушастой личины нанесена необычная тамга, не имеющая аналогов в Сарматии (№ 9). Это знак одного из ияарей Хорезма, ставивщего их на монетах, T.5 по классификации Б.И. Вайнберг [Вайнберг, 1977, табл. 7]. Как мы теперь знаем, торговые интересы позднеантичного Хорезма в сарматском мире обычно не простирались далее Южного Урала. Однако, например, в поздний период функционирования храма Байте III на тогдашнем торговом пути через плато Устюрт (когда в нем присутствуют и высокая доля тамг кланов из разных частей Сарматии, и практически все ранние известные тамги царей Хорезма). При этом в скоплении 3 (то есть в расположенной напротив входа, в «святая святых» храма) рядом размещень один из ранних знаков царей Хорезма и знак одного из аристократических кланов Правобережной Украины [Яценко и др., 2019 , с. 77,82 , рис. 6 , № 177, № 265]. Есть в Байте, кстати, и интересующий нас хорезмийский знак Т.5. Видеть знак одного из царей Хорезма на криворожской личине не более странно, чем обнаружить знак другого, близкого по времени, царя этой страны на кангюйском петроглифе в Жалтырак-Таш, в верховьях р. Талас в кыргызстанском Тянь-Шане, где он вырезан на бедре крылатой собаки [Яценко и др., 2020, рис. 6-9]. Не забудем и о том, что в Хорезме римского времени изображения божества со звериными ушами, например, занимали почетное место в царском дворце, в знаменитом Зале танцующих масок [Топрак-кала, 1984, с. 79-85]. Замечу также, что знак № 1 (доживший на Правобережной Украине до середины III в.) почти идентичен знаку Т.10 на монетах хорезмийского Бивасара рубежа III-IV вв., и то же можно сказать о ранней донской тамге № 13 в связи с самым поздним царем с хорезмийских монет с тамгой Т.14. Знак № 14 имеет точный аналог только в Кангюе эпохи его расцвета и локализируется в его предполагаемом политическом центре в долине р. Арысь [Яценко и др., 2019, c. 164 , рис. $1,(8), 1]$. Второй знак кангюйского происхождения (№ 42) найден на фляге III начала IV вв. н.э. в крепости Бока-тобе в низовьях Таласа [Яценко и др., 2020, с. 161-162, рис. 6-10]. Этот же знак изображен при вторичном использовании на 3-й стадии нанесения серии тамг (в первой половине III в. н.э.) на плите № 44 по Э.И. Соломоник из Пантикапея [Яценко, 2002, рис. 1,d,№ 11] и на амфо- 
pe III-IV вв. из Кеп [Емец, 2012, с. 208, № 740]. Все три среднеазиатских тамги относятся к позднему этапу «заполнения» плиты, причем два знака из трех вписаны в узкое пространство внутри личины, то есть - в самом значимом месте композиции.

Два знака происходят из «варварской» части Крыма: ранний № 14 (миска начала II в. из могилы 9 в Битаке) и поздний № 40 (рукоять ножа из могилы 194 в Нейзаце) [Яценко, 2018б, рис. 3,№ 4, 11,№ 3]. Крымские знаки находятся рядом, примыкая слева к личине. Остальные определимые мелкие знаки все ранние и представляют регионы по одному экземпляру: местный (Правобережная Украина) № 37 (5/81), № 27 из Северного Приазовья (близкий аналог: 5/61) и № 17 с Европейского Боспора (Семеновка) [Яценко, 2009, рис. $1, I, a, 2]$. Напомню, что на левом торце плиты в небольшой углублении сохранившиеся две линии и знак, нанесенные красной краской (рис. 1). Такая тамга известна в скоплении знаков на одной из плит в Танаисе [Яценко, 2001, рис. 22, $A$,№ 1].

2. Плита из Горгиппии, инв. № 50041 (рис. 3). Этот памятник выглядит не менее оригинально. Э.И. Соломоник казалось, что вся верхняя часть плиты отбита, так как она была уверена, что здесь должны были изображаться полные фигуры или полуфигуры мужчин. Мысль о том, что здесь представлен обряд побратимства, высказана в 1933 г. П.Н. Шульцем [Соломоник, 1959, с. 76]. Однако реальное знакомство с плитой никоим образом не подтверждает заключения Э.И. Соломоник. В более позднее время слегка пострадал лишь маленький участок у верхнего края внутреннего левого торца. На этом торце вверху имеется небольшое прямоугольное углубление для упора какой-то балки, возможно, сделанное в поздний период. Узкая полоска сколов идет также по краю внешнего торца верней площади (в левой его половине). Плита, как и предыдущая, не пилилась, а обкалывалась для придания ей нужной (впрочем - весьма аморфной) формы: так, верхний правый угол изначально имел скос вниз. Природный выступ каменной плоскости сужается небольшой ступенькой вдоль основания «шипа». Мастера, как и в Кривом Роге, использовали естественно образовавшуюся поверхность плиты, но здесь они не стали ее спе- циально выравнивать сзади, и на тыльной стороне осталось несколько довольно крупных природных каверн (по отношению к лицевой стороне - в двух местах ниже правого края верхней площадки, вдоль левой части основания «шипа» и выше этого места). Однако основная плоскость, левый торец и верхняя площадка выглядят достаточно ровными (в нижней правой части основной плоскости есть три небольших каверны). Нет никаких оснований думать, вслед за Э.И. Соломоник, что резчик хотел создать полные фигуры людей; наоборот, здесь изначально изображались только руки до плеч без остальных частей тела.

Общая композиция не имеет аналогов и очень интересна, хотя выполнена она примитивно, и говорить о «художественном уровне мастера» просто не приходится. Основные изображения здесь выполнены не гравировкой, а рельефно. Здесь представлены три руки, держащие в руках довольно высокие цилиндрические бокалы или кубки (с алкогольным напитком? с кровью?) (рис. 3,(1)-(3)). Руки (1) и (3) (и соответственно - невидимые нам их хозяева) обращены в сторону центральной из рук (2) (у нее подчеркнут декор бокала в виде каннелюров). Речь идет о заключении некой клятвы или договора. Исследователи в подобных ситуациях обычно ищут параллели в текстах Геродота (Her. IV, 70) и Лукиана (Luc. Tox. 37) [Хазанов, 1972, с. 68]. Однако у Геродота говорится не о побратимстве, а о соглашении у скифов. Что касается «скифов»- современников аланов у Лукиана, то описанные их обычаи в целом не соответствуют тому, что мы знаем для скифов у всех других авторов, и я давно полагаю, что под «скифами» здесь скрывается иной этнос. У Лукиана «скифы» действительно совершают обряд побратимства, но пьют кровь из одного сосуда вместе, а не каждый из своего. Вместе с тем, значимо его свидетельство, что важное соглашение у причерноморских кочевников заключали сразу не более трех человек (что мы и видим на горгиппийском рельефе). Замечу, что $и$ лунок для приношений на верхней плоскости тоже три, столько же и тамг участников соглашения на основной плоскости плиты. Кроме рук с бокалами, здесь есть еще две руки, владельцы которых совершают иные действия. Вверху одна такая рука поднята вверх, види- 
мо - для молитвы. У другой руки (внизу справа) очень грубо показана только большая кисть, и она протянута к единственному крупному предмету, лежащему (?) перед договаривающимися. Думается, это очень примитивно переданный колчан для стрел с поясом для него (он украшен накладными прямоугольными бляшками). Мотив колчана со стрелами - один из самых частых в искусстве ранних кочевников, и в последнее время он трактуется либо в контексте смерти и представлений о загробном мире, либо в контексте героизащии [Вертіенко, 2014, c. 36-42]. Именно второй аспект, вероятно, и подразумевается на плите из Анапы.

Очень интересны тамги трех участников некоего соглашения. Верхний знак № 1 связан с «варварскими» частями Крыма среднесарматского времени, и встречен там неоднократно (5/11). Следующий крупный знак № 2 один близок синхронному образцу из того же района $(5 / 12)$, а точная аналогия известна в скоплении знаков на одной из еще не опубликованных плит из Танаиса, найденных в 1993 г. Третий, маленький знак № 3 также происходит из Крыма, но уже позднесарматского времени (6/10). Он же известен на стене склепа 1/1 второй половины II в. н.э. в Старожилово на Европейском Боспоре и принадлежит крупному боспорскому военачальнику (хилиарху-тысячнику), видимо, сарматского происхождения [Яценко, 2009, рис. 1, II, a,№ 11]. Вероятно, этому малому знаку на периферии плоскости плиты соответствует самая маленькая рука с бокалом в правом углу. Итак, участники соглашения - представители трех кланов из «варварских» районов Крыма, которые (судя по одному позднему знаку) заключили его около второй половины II в. н.э. Думается, все изображения были нанесены одновременно. Однако, кроме этого, здесь гравированы еще две, очень маленькие тамги: на левом торце и на верхней площадке. Знак № 3 на верхней плоскости связан с Европейским Боспором позднесарматского времени (Семеновка, где представлен его зеркальный вариант: см. 6/52). Идентичные же образцы неоднократно представлены в основных тогдашних зонах тамгопользования ${ }^{2}$ в Средней Азии [Яценко, 2001, рис. 28, № 158]. Знак № 4 на торце представлен на глиняном бычке из могилы 312 на Глинице в Керчи [Соломоник, 1959, № 143] (в этой детской могиле найдены два глиняных бычка, дышло и модель кочевой кибитки на колесах; последняя заполнена игральными костями-альчиками и положена на крышку гроба). Подобные бычки пантикапейского происхождения, начиная с первой половины I в. н.э., судя по недавней датировке этой могилы ${ }^{3}$, производились короткое время и парами сопровождали модель кочевой повозки. Такой комплекс, вероятно, связан с некой сарматской группой, проникшей в I в. н.э. в боспорскую столицу (ср.: [Яценко, 1994]).

Итак, все тамги основной поверхности связаны с крымскими «варварами» (сарматизованными поздними скифами или крымскими сарматами), жившими вне античных государств полуострова, а знаки боковых плоскостей - с синхронными сарматскими кланами, обосновавшимися на Европейском Боспоpe. Возникает закономерный вопрос: почему эти плиту в таком случае разместили не в самом Крыму, а вне его, по другую сторону пролива в Анапе / Горгиппии? Этот вопрос пока остается без ответа. Возможно, речь идет о людях, приехавших туда специально, по важному поводу. В популярные рассказы об обилии древних плит, которые в XIX в. в Причерноморье загружали в корабли в качестве балласта, а потом бросали на месте прибытия, я в данном случае верить пока не склонен (тогда сохранность плиты была бы много хуже).

В целом тщательная фиксация Е.И. Шевченко и внимательное изучение двух замечательных сарматских памятников в одесском музее, с учетом появившихся за последние 20 лет новых публикаций, дает нам дополнительные возможности и позволяет сделать ряд новых, во многом неожиданных выводов.

\section{ПРИМЕЧАНИЯ}

1 Здесь и ниже нумерация дается по номеру рисунка и номеру знака в нем по монографии [Яценко, 2001]: рис. 4, № $1=4 / 1$ и т. д. Вначале даются номера тамг на одной из изучаемых здесь плит, а затем - ссылка на их аналоги в монографии.

${ }^{2}$ Современное, международное признанное определение термина «тамгопользование» и его составляющих см. [Яценко и др., 2019, с. 21-22].

3 Любезное сообщение А.М. Бутягина, февраль 2021 г. 


\section{ИЛЛЮСТРАЦИИ}

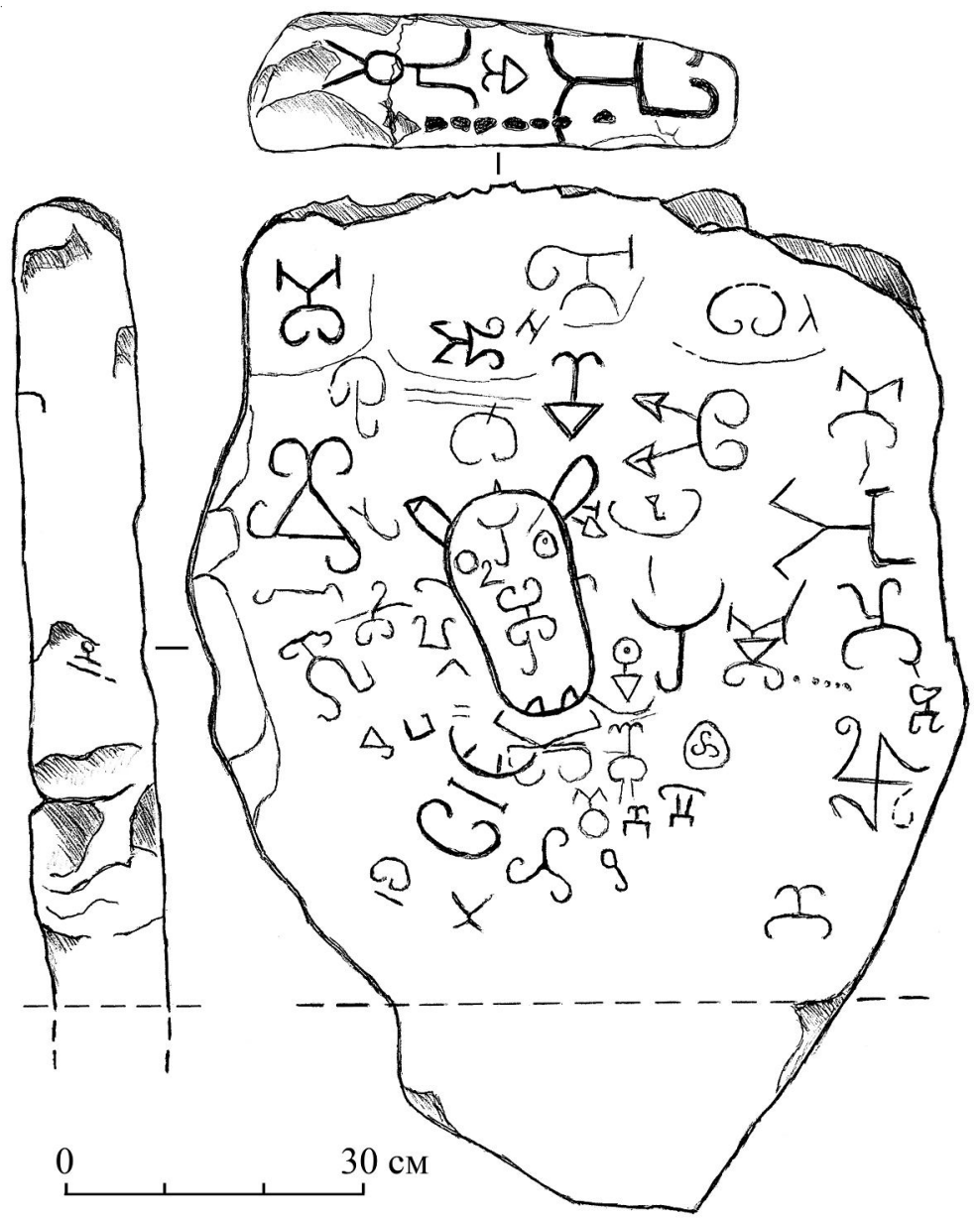

Рис. 1. Плита из Кривого Рога. Покупка 1887 г. Рис. автора

Fig. 1. The stone slab from Krivyi Rih. Purchased in 1887. Author's drawing 


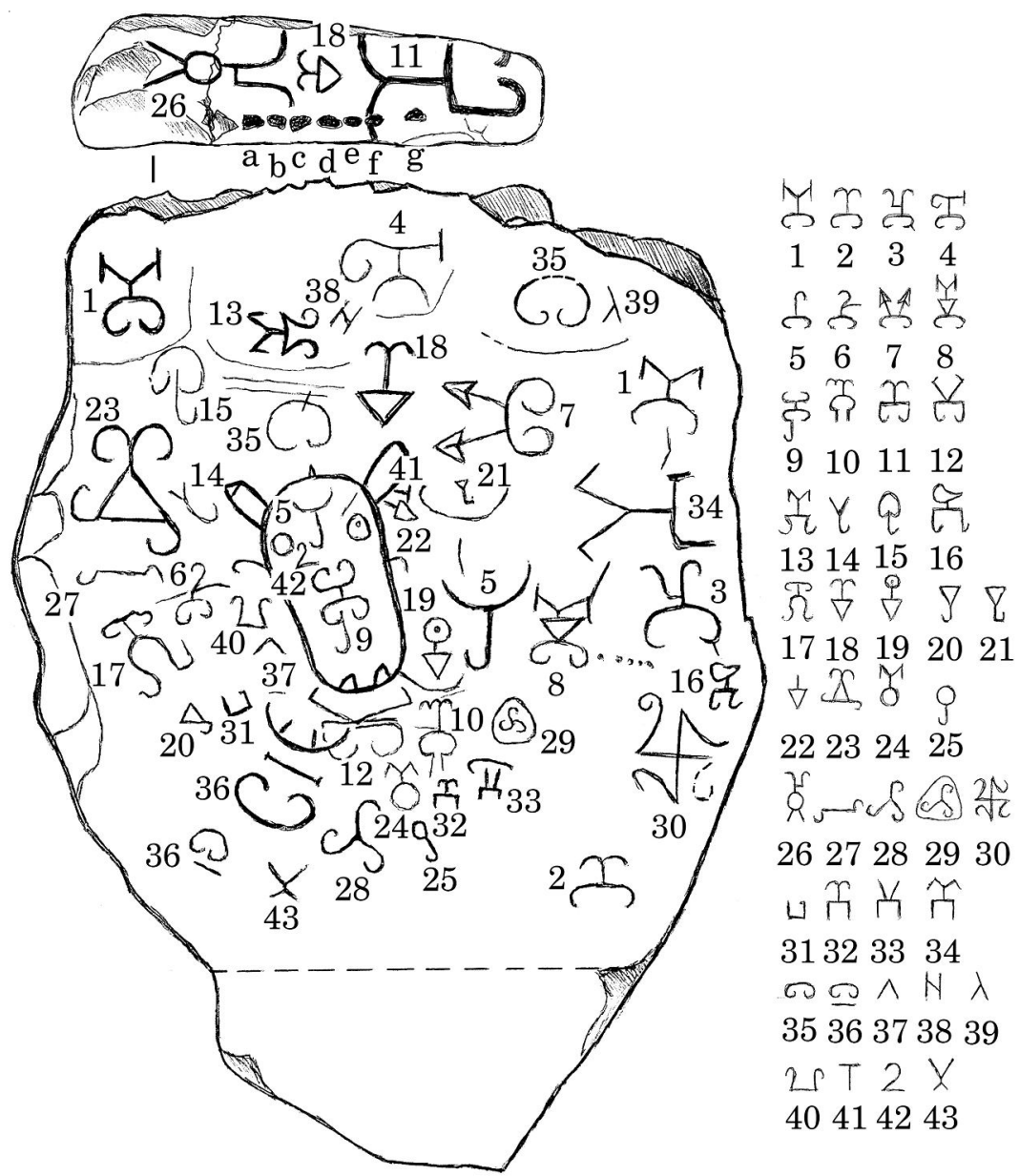

Рис. 2. Плита из Кривого Рога. Нумерация тамг и ямок для жертвоприношений. Рис. автора

Fig. 2. The stone slab from Krivyi Rih. The numeration of tamgas and small sacrificial recesses. Author's drawing 


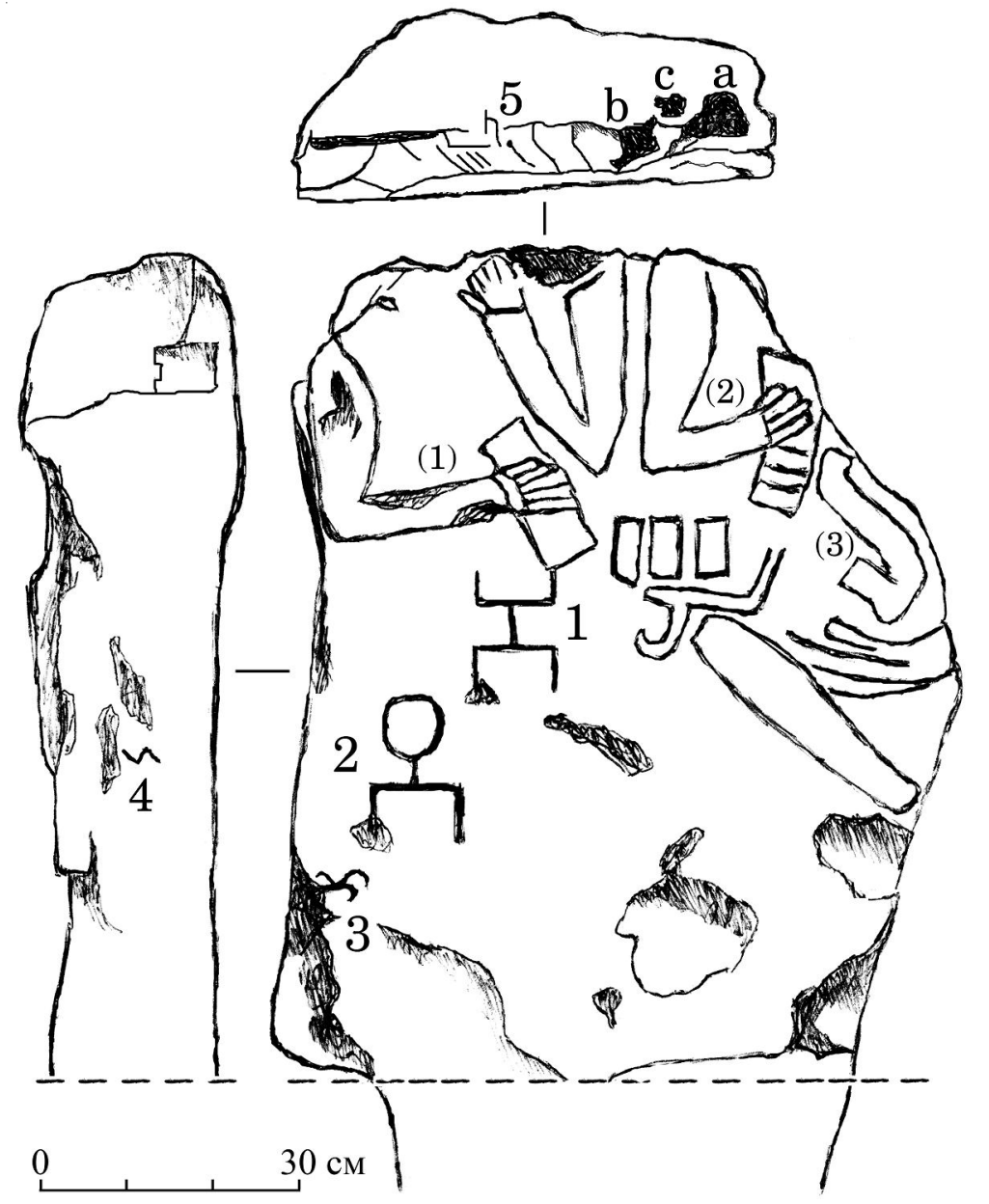

Рис. 3. Плита из Горгиппии / Анапы. Дата покупки неизвестна. Рис. автора

Fig. 3. The stone slab from Anapa / Gorgippia. The purchase date is unknown. Author's drawing 


\section{СПИСОК ЛИТЕРАТУРЫ}

Вайнберг Б. И., 1977. Монеты древнего Хорезма. М. : Наука. 194 с.

Вертіенко Г. В., 2014. Іконографія скіфської есхатології. Київ : Інститут сходнознавства НАН Украни. 224 с.

Емец И. А., 2012. Граффити и дипинти из античных городов и поселений Северного Причерноморья (подготовительные материалы к Корпусу). М. : Спутник +. 478 с.

Ильюков Л. С., 2000. Позднесарматские курганы левобережья реки Сал // Сарматы и их соседи на Дону. Ростов н/Д: Терра. С. 100-140.

Козыренко И. И., 1957. Тамги на археологических памятниках Одесского Государственного Археологического музея // Материалы по археологии Северного Причерноморья. Вып. 1. Одесса : Одесский гос. археологический музей. С. 91-96.

Соломоник Э. И., 1959. Сарматские знаки Северного Причерноморья. Киев : Изд-во АН УССР. 180 с.

Топрак-кала. Дворец, 1984. М. : Наука. 304 с.

Хазанов А. М., 1972. Обычай побратимства у скифов // Советская археология. № 3. С. 68-75.

Юргевич В. Н., 1889. Камень с загадочными знаками, хранящийся в Музее Одесского Общества Истории и Древностей // Записки Одесского общества истории и древностей. Т. XV. Одесса. С. 504-505.

Яценко С. А., 1992а. Антропоморфные изображения Сарматии // Аланы и Кавказ (Alanica - II). Владикавказ, Цхинвал: СО ИГИ. С. 189-214.

Яценко С. А., 1992б. О преемственности мифологических образов ранних и средневековых аланов // Проблемы этнографии осетин. Вып. 2. Владикавказ : Северо-Осетинский НИИ истории, филологии и экономики. С. $64-80$.

Яценко С. А., 1994. Изображения аланских кочевых кибиток в погребальном ритуале боспорских городов IIII вв. н.э. // Боспорский сборник. Вып. 4. М. : НИИЦ «Архэ». С. 19-23.

Яценко С. А., 2001. Знаки-тамги ираноязычных народов древности и раннего средневековья. М. : Вост. лит. $190 \mathrm{c}$.

Яценко С. А., 2002. О последовательности нанесения серии тамг на надгробные плиты из некрополя Пантикапея // Боспорский феномен. Погребальные памятники и святилища. Ч. 1. СПб. : Изд-во Гос. Эрмитажа. С. 79-82.

Яценко С. А., 2009. Знаки собственности сарматского облика (gakk/nishan) в сельских районах Боспорского царства I-ІІІ вв. н.э. // Древности Боспора. Т. 13. М. : Институт археологии РАН. С. 539-552.

Яценко С. А., 2018а. Возможности анализа планиграфии малых сарматских некрополей // Древние некрополи: погребально-поминальная обрядность, погребальная архитектура и планиграфия некрополей. СПб. : ИИМК РАН, Гос. Эрмитаж. С. 224-231.

Яценко С. А., 2018б. Планиграфия знаков-тамг в некрополях оседлого населения Сарматии // Stratum plus. № 6. С. 217-242.

Яценко С. А., Рогожинский А. Е., Смагулов Е. А., Табалдыев К. Ш, Баратов С. Р., Ильясов Дж. Я., Бабаяров Г. Б., 2019. Тамги доисламской Центральной Азии. Самарканд : Междунар. ин-т центральноазиат. исслед. $452 \mathrm{c}$.

Яценко С. А., Авизова А. К., Торгоев А. И., Саипов А., Кулиш А. В., Китов Е. П., Рогожинский А. Е., Смагулов Е. А., Ержигитова А. А., Торежанова Н. Ж., Тур С. С., Иванов С. С., 2020. Археология и история Кангюйского государства. Шымкент : Әлэм. 288 с.

Perrin O. T., Evans Pim J., Yatsenko S. A., 2010. Mark Studies : An Interdisciplinary Approach // Traditional Marking Systems : A Preliminary Survey. London, Dover : Dunkling Books. P. 7-22.

\section{REFERENCES}

Vainberg B.I., 1977. Monety drevnego Khorezma [Coins of the Ancient Khorezm]. Moscow, Nauka Publ. 194 p. Vertienko G.V., 2014. Ikonografiia skifs'koy eskhatologii [Iconography of Scythian Eschatology]. Kyiv, Institute of Oriental Studies NAS of Ukraine. $224 \mathrm{p}$.

Emets I.A., 2012. Graffiti i dipinti iz antichnykh gorodov i poselenii Severnogo Prichernomor'ya (podgotovitel'nye materialy k Korpusu) [Graffiti and Dipinti from the Antique Cities and Settlements of the North Black Sea Region (The Preparatory Materials for Corpus)]. Moscow, Sputnik+ Publ. 478 p. 
Il'yukov L.S., 2000. Pozdensarmatskie kurgany levoberezh'ya reki Sal [The Late Sarmatian Barrows of the Left Bank of Sal River]. Sarmaty i ikh sosedi na Donu [Sarmatians and Their Neighbours in Don Basin]. Rostov-onDon, Terra Publ., pp. 100-140.

Kozyrenko I.I., 1957. Tamgi na arkheologicheskikh pamyatnikakh Odesskogo Gosudarstvennogo Arkheologicheskogo muzeya [Tamgas on the Archaeological Artifacts from Odessa State Archaeological Museum]. Materialy po arkheologii Severnogo Prichernomor'ya [The Materials on the Archaeology of the North Black Sea Region], iss. 1. Odessa, Odessa State Archaeological Museum, pp. 91-96.

Solomonik E.I., 1959. Sarmatskie znaki Severnogo Prichernomor'ya [Sarmatian Signs of the North Black Sea Region]. Kiev, Ukrainian SSR Academy of Sciences. 180 p.

Toprak-kala. Dvorets [Toprak-kala. Palace], 1984. Moscow, Nauka Publ. 304 p.

Khazanov A.M., 1972. Obychay pobratimstva u skifov [The Twinning Tradition of Scythians]. Sovetskaya arkheologiya [Soviet Archaeology], no. 3, pp. 68-75.

Yurgevich V.N., 1889. Kamen’s zagadochnymi znakami, khranyashchiisya v Muzee Odesskogo Obshchestva Istroii i Drevnostei [The Stone with the Mysterious Signs, Stored in the Museum of Odessa Society of History and Antiquities]. Zapiski Odesskogo obshchetva istorii i drevnostei [Notes of Odessa Society of the History and Antiquities], vol. XV. Odessa, pp. 504-505.

Yatsenko S.A., 1992a. Antropomorfnye izobrazheniya Sarmatii [The Anthropomorphic Images of Sarmatia]. Alany i Kavkaz (Alanica - II) [Alans and Caucasus (Alanica - II). Collection of Scientific Articles]. Vladikavkaz, Tskhinval, Northern Ossetian Institute of the Humanities Studies, pp. 189-214.

Yatsenko S.A., 1992b. O priemstvennosti mifologicheskikh obrazov rannikh i srednevekovykh alanov [On the Continuity of Mythological Images of the Early and Medieval Alans]. Problemy etnografii osetin [Problems of Ossetians' Ethnology], iss. 2. Vladikavkaz, Northern Ossetian Institute of History, Philology and Economy, pp. 64-80.

Yatsenko S.A., 1994. Izobrazheniya alanskikh kochevykh kibitok v pograbal'nom rituale bosporskikh gorodov I-III vv. n.e. [The Images of Alanian Nomadic Mobile Houses in the Burial Ritual of Bosporan Cities of the $1^{\text {st }} 3^{\text {rd }}$ cc. CE]. Bosporskiy sbornik [Bosporan Collection], iss. 4. Moscow, “Arhe” Tsenter, pp. 19-23.

Yatsenko S.A., 2001. Znaki-tamgi iranoyazychnykh narodov drevnosti i rannego srednevekov'ya [Tamga-Signs of the Iranian-Speaking Peoples of the Antiquity and the Early Middle Ages]. Moscow, Vostochnaya literatura Publ. 190 p.

Yatsenko S.A., 2002. O posledovatel'nosti naneseniya serii tamg na nadgrobnye plity iz nekropolya Pantikapeya [On the Sequence of Engraving of Signs on the Tombstones from Panticapaeum Necropolis]. Bosporskiy fenomen. Pograbal 'nye pamyatniki i svyatilishcha. Chast' 1 [Bosporan Phenomenon. The Burial Monuments and Sanctuaries. Part. 1]. St. Petersburg, Hermitage Museum, pp. 79-82.

Yatsenko S.A., 2009. Znaki sobtvennosti sarmatskogo oblika (gakk/nishan) v sel'skikh raionakh Bosporskogo tsarstva I-III vv. n.e. [Property Signs of Sarmatian Types (gakk/nishan) in the Rural Regions of Bosporus Kingdom of the $1^{\text {st }}-3^{\text {rd }}$ cc. CE]. Drevnosti Bospora [The Antiquities of Bosporus], vol. 13. Moscow, IA RAS, pp. 539-552.

Yatsenko S.A., 2018a. Vozmozhnosti analiza planigrafii malykh sarmatskikh nekropoley [The Opportunities of Planigraphy Analysis of the Small Sarmatian Necropolises]. Drevnie nekropoli: pogrebal'no-pominal'naya obryadnost' i planigrafiya nekropolei [Ancient necropolises: funeral and memorial ritualism, architecture and planning of necropolises]. St. Petersburg, IHMC RAS, Hermitage Museum, pp. 224-231.

Yatsenko S.A., 2018b. Planigrafiya znakov-tamg v necropolyakh osedlogo naseleniya Sarmatii [Planigraphy of the Tamga-Signs in the Necropolises of Sedentary Population of Sarmatia]. Stratum plus, no. 6, pp. $217-242$.

Yatsenko S.A., Rogozhinskii A.E., Smagulov E.A., Tabaldyev K.Sh., Baratov S.R., Ilyasov J.Ya., Babayarov G.B., 2019. Tamgas of Pre-Islamic Central Asia. Samarkand, IICAS. 452 p.

Yatsenko S.A., Avizova A.K., Torgoev A.I., Saipov A., Kulish A.V., Kitov E.P., Rogozhinskii A.E., Smagulov E.A., Erzhigitova A.A., Torezhanova H.Zh., Tur S.S., Ivanov S.S., 2020. Arkheologiya i istoriya Kangyuiskogo gosudarstva [Archaeology and History of Kangju State]. Shymkent, Älém Publ. 288 p.

Perrin O.T., Evans Pim J., Yatsenko S.A., 2010. Mark Studies: An Interdisciplinary Approach. Traditional Marking Systems: A Preliminary Survey. London, Dover, Dunkling Books Publ., pp. 7-22. 
S.A. Yatsenko. Two Sarmatian Stone Slabs with Tamgas in Odessa Archeological Museum Collections

\section{Information About the Author}

Sergey A. Yatsenko, Doctor of Sciences (History), Professor, Department of the History and Theory of Culture, Russian State University for the Humanities, Miusskaya Sq., 6, 125993 Moscow, Russian Federation, sergey_yatsenko@mail.ru, https://orcid.org/0000-0002-5103-9736

\section{Информация об авторе}

Сергей Александрович Яценко, доктор исторических наук, профессор кафедры истории и теории культуры, Российский государственный гуманитарный университет, Миусская пл., 6, 125993 г. Москва, Российская Федерация, sergey_yatsenko@mail.ru, https://orcid.org/0000-0002-5103-9736 